\title{
Budget Deficit-Inflation Nexus in South Africa: VAR Analysis
}

\author{
John Khumalo \\ Department of Economics, UNISA, South Africa \\ Email:khumamj@unisa.ac.za
}

\section{Doi:10.5901/mjss.2013.v4n14p725}

\begin{abstract}
The study uses the quarterly data covering the period 1980 - 2012 to empirically examine the impact of budget deficit on inflation in South Africa with the view to find the direction of causation and establish any cointegration existence. The study uses the Vector Autoregression (VAR) analysis coupled with the impulse response functions. Prior to getting the research results, the data is tested for unit root using the Augumented Dickey-Fuller (ADF) test and the Philips-Perron (PP) test. The Granger causality test is also conducted to establish the direction of causation between variables included in the model as well as the cointegration. The unit root test results reveal that inflation rate, budget deficit, money growth, import prices, foreign rate of interest and GDP growth are integrated of order zero and causality runs from budget deficit to inflation. There is also evidence of long run relationship between budget deficits and inflation in South Africa and the findings suggest that the VAR model produces sensible impulse functions and reveal that budget deficits are inflationary. The study shows that budget deficit contribute positively to inflation. The policy recommendations arising from the study are that the government should cut the size of its expenditures and to maintain the growth rate of money at the level which will not be inflationary.
\end{abstract}

Keywords: VAR, budget deficit, inflation, cointegration, impulse response functions

\section{Introduction}

Many economists argue that inflation is strictly a monetary phenomenon and that inflation occurs when the rate of growth of the money supply is higher than the growth rate of the economy. This is the conventional monetarist linkage from the creation of base money to inflation when the central bank issues money at the rate that exceeds the demand for cash balances at the existing price level. The increased demand in the goods market pushes up the price level as the public tries to get rid of its excess cash holdings. It is the contention of these economists that the central bank can eliminate the link between budget deficits and inflation by refusing to monetize the deficit. Higher deficit policies may lead to inflation if the deficit is financed through money creation though they may also increase price level even if the deficit is financed through the sale of bonds. But the rate might not be as high as it would be the case with money creation. The government borrowing requirement will increase the net credit in the economy, drive up the interest rates resulting into crowding out of private investment. The reduction in the growth rate of the economy will lead to a decrease in the amount of goods available for a given level of cash balances and hence the increase in the price level.

Since the 1980's, there has been a growing consensus on the importance of macroeconomic stability and much emphasis was placed on price stability and exchange rate stability. Price stability in South Africa remains the overriding long-term objective for monetary policy. However, budget deficits seem to disturb the economy in that they lead to inflation if monetized. Budget deficit occurs if the government is forced to spend beyond its tax revenue. In order to clear the deficit the government needs to either borrow or create money, but under certain conditions (e.g. in a growing economy) creation of money leads to seigniorage revenue. Leeper (1991) describes a situation where fiscal deficits imply that inflation will eventually occur as the one where there is an active fiscal policy and a passive monetary policy. Such a situation is also described as a fiscal dominance. With fiscal dominance, an increase in government debt will eventually require an increase in seigniorage. A contractionary monetary policy aimed at producing lower inflation will initially lower seigniorage revenue and requires that additional debt be issued. This ultimately leads to higher inflation. If the fiscal authority does not adjust, the monetary authority will be forced eventually into producing higher inflation.

The loss of public confidence in monetary or exchange rate targeting regimes has forced banks to look for a credible nominal anchor. In this context, many countries have recently adopted explicit inflation targeting as their monetary policy regime. South Africa is following this example, as the reserve bank puts in place as rapidly as feasible a formal inflation targeting framework. Price stability in any economy depends solely on the central bank independence and the financial market development. If the central bank is not independent enough to block out the external forces that 
would compel it to create money so as to finance the deficit, then the country is likely to experience high inflation. This therefore suggests that inflation management lies in the hands of the reserve bank (central bank) and the financial market.

Global consumer price inflation accelerated very little in the year 2012 and this brought some concern regarding the rise in the budget deficit and the international oil prices. Almost all countries experience the problem of high budget deficit associated with high inflation. It is in rare cases that a particular country will have a balanced budget. If government's spending exceeds its revenue, the resulting deficit has to be financed either through borrowing or through issuing of money. Borrowing by the government is limited by the public's capacity or willingness to hold additional government debt and monetary expansion leads to inflation.

The South African Reserve Bank (1996) has attributed the slow-down in inflation during the first half of the 1990s to the consistent application of conservative monetary policy since the late 1980s and the impact of the drawn out recession of 1989-1993 on inflation expectations and wage settlements. These factors were supported by the relative price stability in South Africa's main trading partner countries and a somewhat more stable exchange rate of the Rand. During the past four decades inflation in South Africa seldom entered the moderate range, defined by Dornbusch and Fischer (1993) as persistent annual rates of price increases ranging between 15 and $30 \%$.

Figure 1: Inflation versus budget deficits

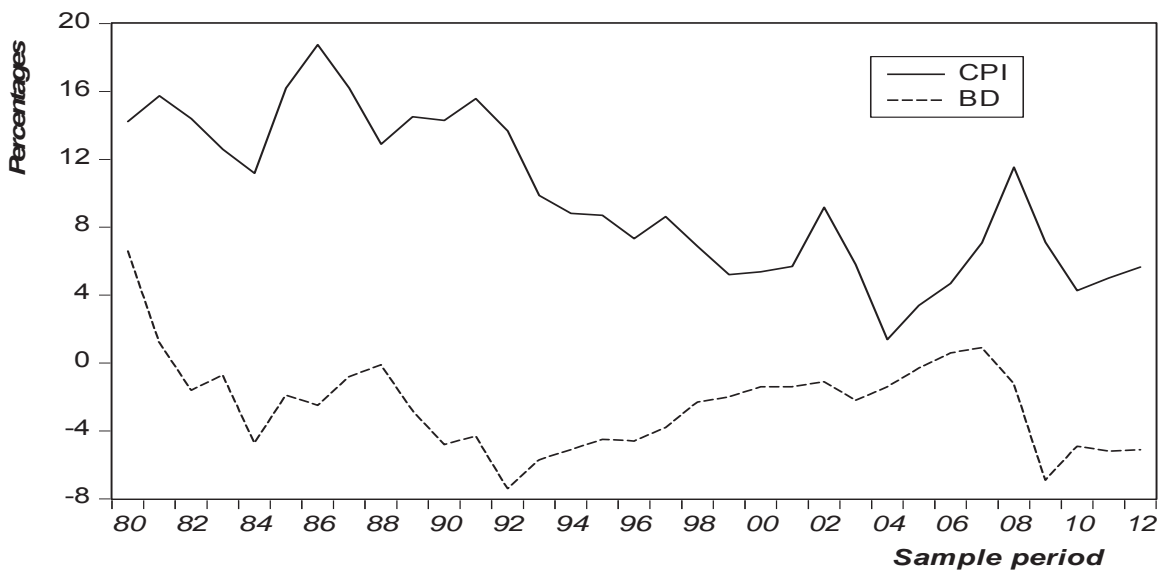

Inflation is expressed as the annual percentage change in the consumer price index (CPI). Inflation was relatively low until the early 1970s, averaging $2.5 \%$ during the 1960 s. It subsequently accelerated and entered the double-digit range in 1973. During the 1970s, the average inflation rate was $10.3 \%$. After a period of relative stability around a level of $11 \%$ in the late 1970s, inflation rose again in the early 1980s. The 1980s were characterised by high, but relatively stable rates of inflation ranging from 11.5 to $18.6 \%$. The average inflation rate for the decade was $14.7 \%$. Inflation subsided significantly in the early part of the 1990s. After peaking in 1986, the rate of inflation began decreasing and in 1993 it dropped to beneath 10\%. It subsequently decreased further to $5.2 \%$ in 1999 . On average, consumer prices rose by $9.3 \%$ during the 1990s. Money supply and budget deficit were seen to be increasing in those years. As budget deficit increased money supply also increased, which might provide an indication that the deficit was monetized and that resulted into inflation.

South Africa's huge budget deficits to finance its numerous public sector undertakings and persistent high inflation rates in the last two decades have only created massive poverty and a potentially explosive socioeconomic environment. The country's dismal economic performance raises in the minds of domestic policy makers as well as foreign advisors the basic question of how to control inflation and thereby bring back the economy into track. The relationship between the two variables (budget deficits and inflation) now brings us back to the classic policy debate between the Keynesians and the monetarists. The former would argue for drastic reduction in South Africa's budget, whereas the monetarist would emphasize on stringent control over the country's money supply.

South Africa experienced a massive budget deficit, high growth rates of money accompanied by high rate of inflation. Each economy tries to establish a balanced fiscal policy as one of its macroeconomic policy conducts. If South 
Africa continues to register some increments in the budget deficit it will continue to have a high rate of inflation and a target range will not be reached. An inflation rate of 5.2 percent was registered in 1999 with the deficit standing at 2.8 percent, but in the following year inflation was 5.3 while budget deficit was at 5.4 percent. Policy makers view deficit and inflation as hazardous to the economy if the latter happens to be persistent. But if the deficit remains unchecked it impedes on the flexibility of policy making and consequently hampers economic growth. Thus eliminating large budget deficit is a necessary condition for achieving price stability. What then should the fiscal and monetary authorities do to maintain price stability while trying to get rid of the budget deficit?

\section{Literature review}

This section discusses the related literature on the subject. We explore both the theoretical and empirical literature. Under the theoretical literature we explore how the respective variables enter the model, thus helps to determine the main determinants of inflation. The empirical literature provides a summary of existing studies on the subject. The theoretical literature section demonstrates how money growth and budget deficits affect inflation.

\subsection{Theoretical Literature}

The tax cut and the attendant increase in the deficit have two major stimulative effects. First, the tax cut increases disposable income. Second, if the deficit is increased, there is an increase in net private sector financial assets. This follows from the equilibrium condition

$$
I+G=S+T
$$

which can be written as

$$
G-T=S-I
$$

Where $\mathrm{I}$ is investment, $\mathrm{G}$ is government spending, $\mathrm{S}$ is national saving and $\mathrm{T}$ is the tax revenue, $G-T$ is the government deficit. The stimulative effect of the tax cut and deficit increase is represented by an upward shift of the IS curve. The expansionary effect of the shift in IS curve will depend on whether the LM curve shifts or not. The movement of the LM curve will depend on how the deficit is financed. If additional reserves provided to the commercial banks are created, the money supply increases and the LM shifts to right, adding to the expansionary effect of the deficit. This ultimately leads to a rise in the general price level (Branson, 1989)

Each government has its budget constraint; it has to pay its bills just like individuals households do. It enjoys the two options of paying its bills. It raises revenue by levying taxes or going into debt by issuing government bonds. Ways of financing government spending are well defined by an expression known as the government budget constraint: which states that government budget deficit (BD) which is equal to the excess of government spending (G) over tax revenue (T) must equal the sum of changes in the monetary base ( $\triangle M B$ ) and the change in government bonds held by the public $(\Delta B)$. Algebraically, we can write:

$$
B D=G-T=\Delta M B+\Delta B
$$

The government's constraint reveals two facts. If the government deficit is financed by an increase in bond holding by the public, there is no effect on the monetary base and hence on the money supply. But if the deficit is not financed by increased bond holdings by the public, the monetary base and the money supply increase. This boils down to inflation if the quantity theory holds. Financing a persistent deficit by money creation will lead to a sustained inflation (Mishkin 1997). If it is temporary, it would not produce inflation. In the period when the deficit occurs, there will be an increase in money to finance it, and the resulting rightward shift of the aggregate demand curve will raise the price level. This tells us that a deficit can be a source of a sustained inflation only if it is persistent rather than temporary and if the government finances it by creating money rather than by issuing bonds to the public. If we assume a non -interest bearing debt, we can write budget identity as:

$$
G-T=\Delta H
$$

or

$$
\frac{G-T}{P Y}=\frac{\Delta H}{P Y}
$$


Where $\mathrm{G}$ is the public sector expenditure, $\mathrm{T}$ is the public sector revenues, $\mathrm{Y}$ is the real income, $\mathrm{P}$ is the price level and $\mathrm{H}$ is the base money. In a steady state growing economy, it follows that

$$
\begin{aligned}
\Delta\left(H^{*}\right) & =\left(H^{*}\right)\left(\frac{\Delta H}{H}-\frac{\Delta P}{P}-\frac{\Delta Y}{Y}\right) \\
& =\frac{\Delta H}{P Y}-H^{*}(\Delta P+\Delta Y)
\end{aligned}
$$

Where $\Delta$ is the difference operator; $H^{\star}, \Delta P$ and $\Delta Y$ are scaled base money $(H / P Y)$, inflation and the growth rate of real income respectively. It is assumed that the long run income elasticity of money is unity. Then the simplified constraint is

$$
\Delta\left(H^{*}\right)=\frac{G-T}{P Y}-H^{*}(\Delta P+\Delta Y)
$$

(8)

When solved for $\Delta P$ we have $\Delta P=c+\alpha_{1} B-\alpha_{2} \Delta Y$

Where $B$ is the scaled budget deficit $((G-T) / H), c$ is the constant term interpretable as the inertial inflation rate and $\alpha_{1}$ and $\alpha_{2}$ are slope coefficients associated with the scaled budget deficit and the income growth. This now states that inflation is explained by base money, budget deficit and real income growth. Sargent and Wallace (1981) proposed an analytical framework, where seigniorage assumes the central role for deficit finance. This proposition views the relation basically as a game between the fiscal and the monetary authorities. Under the assumption that the fiscal authority is the first to make a move, the monetary authority is left with a difficult choice in order to balance the intertemporal budget. It either loses its policy in the short-run to avoid high inflation in the long-run, or tightens its policy today at the expense of an inevitable future increase in inflation. The budget deficit increases and eventually may become unsustainable. In sum, a fiscal dominant regime implies unavoidably a positive intertemporal correlation between deficits and inflation, with causation running primarily from deficits to inflation (Sargent and Wallace 1981).

Another approach argues that the main channel is the effect of inflation on the real value of the stock of debt and on the real interest rate. While Sargent and Wallace (1981) saw their approach as an economic policy game between fiscal and monetary authorities, Keynes (1971) regarded this approach as a social game between rentiers and workers. Society does not tolerate ever-increasing taxes, and therefore, other ways such as inflation must be considered to reduce the accumulated stock of debt. According to this analysis, causation runs from budget deficits to inflation.

The study tries to investigate the role budget deficit and money growth play in the inflationary process in South Africa. The interrelationships between these variables have been at the heart of the monetary economics literature (Ozman, 2012). Budget deficits are inflationary in the monetarist framework only to the extent that they are monetized. Recent studies concentrate on the United States (USA) as well as the European countries and such studies returned inconclusive results because some supported the hypothesis while others did not. This then left a question of "what economics factors countries can target in order to reduce inflation. Dweyer (1982) tested the leading explanations for the positive link between the level of prices and the government deficits and found no significant evidence. Darrat (1985) focused on the link between federal deficits and inflation by relating the rate of change of prices to money supply, deficits and lagged inflation rate. Darrat (1985) concluded that both the money growth and the federal deficits significantly influenced inflation. Akcay, Ozmucur and Alper (1996)'s study whose main aim was to gain an insight into which the channels through which the deficit has been operating in Turkey both in the post world war II era and in the postliberalization era. The short-run dynamics of inflationary process were also analyzed and their study revealed that there were two cointegrating vectors, though the coefficients of deficits and money growth had negative signs. The negativity of the coefficient of GNP implied that an increase in the GNP ratio seemed to imply a lower inflation rate at steady state and an increase in growth of money was associated with lower long-run inflation rate. Akcay, Ozmucur and Alper (1996), however, stated that any linear combination of those two cointegrating vectors was also a legitimate candidate for characterizing the long-run relationship among the three variables and one such combination gave the cointegration relation as money growth and deficits being exogenous variables. The monetarist explanations of inflation have followed the classic study of hyperinflation by Cagan (1956) in stressing that changes in money cause changes in prices. 
Sargent and Wallace (1973) suggested that it was more appropriate to look at causation between money and prices as running from both sides. Frenkel (1977) and Jacobs (1977) also came with the same suggestion. But in their studies, they emphasized that a common explanation for increases in the money supply that led to inflation was due to government's fiscal operations. Apart from these studies, other studies like that conducted by Aghevhi and Khan (1978) have recognized that the increase in the money supply might not be independent of inflation. They introduced the idea that inflation occurs in a widening of fiscal deficits financed through the banking system, more especially by the central bank. If budget deficits were experienced, financing them through money creation would result in the increase in inflation. The purpose of Aghevli and Khan's (1978) study was to examine the link between increases in money supply and inflation in four developing countries, Brazil, Colombia, Dominican Republic and Thailand. Their study first showed that the variables in question were linked in a two-way relation and found a link in the form of reactions of the government fiscal deficits to inflation. The conclusion drawn from that study was that the financing of the deficit through money creation increased money supply and hence inflation. The control of inflation required deliberate action by budgetary authorities if the monetary policy was not to be excessive.

Darrat (2000) reconsidered the inflationary effects of budget deficits after Hondroyiannis and Papapetrou (1997) had denied any direct impact of the deficit on inflation. He pointed out some problems associated with the Hondroyiannis and Papapetrou (1997) results that prices were second-difference stationary but when undertaking the cointegration test dealt with first difference. The second problem of the Hondroyiannis and Papapetrou (1997) results was that they performed the cointegration test in a bivariate setting that included only money and prices, whereas their primary focus was presumably on the role of deficits in the inflationary process. Darrat (2000) re-examined the cointegration relationship among money, prices and deficits using the Johansen-Juselius ${ }^{1}$ cointegration approach and found that the cointegrating vector by Hondroyiannis and Papapetrou (1997) was misspecified. His empirical results reported that, besides money growth, higher budget deficits had also played a significant and direct role in Greek inflationary process.

Tekin-Koru and Ozman (2003) investigated the interrelationships between budget deficits, money growth and inflation in Turkey using trivariate system containing money growth, budget deficits and inflation. Their test results strongly supported the quantity theory of money, that any change in the quantity of money will change prices as well. Choudhay and Parai (1991) also investigated the role of huge budget deficits in Peru's near hyperinflation. That study used the rational expectations macro model of inflation to find out the effect of the anticipated budget deficits on inflation rates by using annual data of Peru for the period 1973:1 to 1988:1. The study found a positive relationship between budget deficits and inflation with money growth acting as an intermediate. Their concluding remarks were that Peru's huge budget deficits as well as high rates of money growth did have significant impact on the high inflation rates during 1973 to 1988.

Neyapti (2012) in his simple model investigated the relationship between budget deficits and inflation with the view that the nature of this relationship depends on the characteristics of the monetary and financial institutions. The main hypothesis of that study was that budget deficits were inflationary when both the central bank was not independent enough and the financial market not developed enough to contain inflationary expectations. The results also suggested that the effect was largely attributed to low degrees of central bank independence and financial market development.

\section{Methodology}

In view of the empirics, there seemed to be mixed findings relating to the relationship between inflation, money growth and budget deficits. The paper aims to establish the relationship between inflation and budget deficit in South Africa, with a view to increase literature on such relationship. To determine the relationship, if any, this study employs a simple VAR analysis. The VAR enables, through the impulse response functions to trace out dynamic responses of the other variables in the model. Such responses allow us to determine if such shocks can be classified as monetary policy shock or fiscal shock.

\subsection{Model specification}

The connection from deficits to inflation is somehow a difficult one to establish for certain reasons. First, empirical studies trying to capture the link between budget deficits and inflation are bound to produce results that are quite sensitive to the choice of the model being used when one considers the number of possible versions that can be constructed. Most of

\footnotetext{
${ }^{1}$ See Johansen (1988) and Johansen \& Juselius (1990)
} 
those studies used the inflation model, while a few used a trivariate system. In view of the discussions above and the adaptation to be followed, the linear regression equation to be estimated takes the following general:

Inflation: $\quad X_{t}=\sum_{i=0}^{n} \beta_{i} X_{t-i}+\sum_{i=0}^{n} \psi_{i} D_{t-i}+\sum_{i=0}^{n} \eta_{i} M_{t-i}+\Pi^{x} \theta_{t}^{x}$

B.deficit:

$$
D_{t}=\sum_{i=0}^{n} \Upsilon_{i} X_{t-i}+\sum_{i=0}^{n} \Theta_{i} D_{t-i}+\sum_{i=0}^{n} \phi_{i} M_{t-i}+\Pi^{d} \theta_{t}^{d}
$$

M. supply: $M_{t}=\sum_{i=0}^{n} \Re_{i} X_{t-i}+\sum_{i=0}^{n}{ }_{i} D_{t-i}+\sum_{i=0}^{n} \varpi_{i} M_{t-i}+\Pi^{m} \theta_{t}{ }^{m}$

Where $\beta_{i}, \psi_{i}, \Pi^{x}, \Upsilon_{i}, \Theta_{i}, \eta_{i}, \phi_{i}, \mathfrak{R}_{i},{ }_{i}, \varpi_{i}$ and $\Pi^{d}$ are square coefficient matrices. The equations above group variables into policy $(\mathrm{D}$ and $\mathrm{M})$, and non- policy $(\mathrm{X})$ blocks. The vector $\mathrm{X}_{\mathrm{t}}$ contains monetary policy variables that are considered as monetary policy indicators, such money supply. We know that the central banks deal indirectly with price stability through interest rates and or money supply. Assuming that the monetary authorities deal price stability (inflation), equations (11) and (12) can be reduced to equations (14) and (15), which could be inverted o give equation (16).

$$
\begin{aligned}
& C_{r}=\theta^{s}+\varphi_{12} \theta^{q} \\
& C_{q}=+\varphi_{21} \theta^{r}+\theta^{q}
\end{aligned}
$$

Equation (4) represents the monetary authority while equation (5) represents the fiscal authority, in this case the budget deficit. Presenting equations (4) and (5) in matrix form and making $\theta^{s}$ the dependent, we arrive at $\theta^{s}=\left[1-b_{12} b_{21}\right]^{-1}\left[\mathrm{C}_{r}-b_{12} C_{q}\right]$

This shows that Equation (6) that monetary policy shock is linear in nature.

\subsection{Data description and estimation}

The study uses time series annual data for the period 1980 to 2012. The variables are: a consolidated budget deficit, which is expressed as ratio of Gross Domestic Product (GDP), growth of money supply as well as the economic growth (GDP) and inflation rate which refers to the growth rate of the consumer price index in South Africa. The data for the analysis was sourced from South African Reserve Bank (SARB), Tradingeconomics.com and Statistics South Africa (StatsSA)

\section{Empirical analysis}

The reliability of the results is done on both a priori criterion as well as on statistical test criterion. The reliability of a priori criterion is determined by the principles of economic theory and refers to the sign of the coefficient of economic theory. On statistical criterion, the statistical theory aims at evaluating statistical reliability of estimates of parameters. Table 1 reports unit root tests results as it is vital to establish the properties of data

\section{Table 1: Unit Roots Test Results}

\begin{tabular}{|l|l|l|}
\hline Variables & ADF statistic & PP Statistic \\
\hline$X_{t}$ & -2.800837 & -2.635030 \\
\hline$D_{t}$ & $-3.776394^{\star \star}$ & $-3.768311^{\star \star}$ \\
\hline$G_{t}$ & $-4.511313^{\star \star}$ & $-4.522162^{\star \star}$ \\
\hline$M_{t}$ & $-3.953754^{\star \star}$ & -2.427180 \\
\hline
\end{tabular}

** denotes significant at 5 per cent.. 


\subsection{Granger ${ }^{2}$ causality analysis}

It is necessary to determine whether money growth and budget deficit play any role in the inflationary process in South Africa. There seems to be no causality between inflation and the growth of money supply between 1980 and 2012. This is justified by the F-value that is insignificant as depicted by its probability value. What this means is that money growth does not cause inflation. This is in contradiction with what the theory postulates that money growth causes increases in prices. Inflation also does not cause money growth. There is no causation between money growth and inflation between 1980 and 2012.

The causality between budget deficit and inflation was tested. The hypothesis that budget deficit does not granger cause inflation is rejected and thus we accepted an alternative (budget deficit granger causes inflation). The probability value for the F-statistic is 0.0825 , which implies that the F-value is highly significant, therefore we conclude that budget deficit does granger cause inflation in South Africa. The opposite, is the case with the null hypothesis that inflation does not granger cause budget deficit. We tend to accept and conclude that there is unidirectional causality with causality running from budget deficit to inflation.

\subsection{Model estimation and results}

The main aim of this paper is to find the macroeconomic impact of budget deficit and money growth on inflation in South Africa using the VAR analysis. Table 2 below presents VAR results.

\section{Table 2: Vector Autoregression (VAR) results}

\begin{tabular}{|c|c|c|c|c|}
\hline & $\mathrm{CPI}$ & $\mathrm{BD}$ & GDP & GMS \\
\hline CPI(-1) & $0.968998^{\star *}$ & 0.166547 & $-0.506021^{* *}$ & 0.566000 \\
\hline & $(0.22777)$ & $(0.16342)$ & $(0.14976)$ & $(0.29951)$ \\
\hline & [ 4.25433] & {$[-1.01915]$} & {$[-3.37879]$} & {$[-1.88974]$} \\
\hline & & & & \\
\hline CPI(-2) & 0.129397 & 0.191062 & 0.197766 & 1.000938 \\
\hline $\mathrm{BD}(-1)$ & 0.114838 & 0.642002 & 0.589466 & 1.123194 \\
\hline & & & & \\
\hline $\mathrm{BD}(-2)$ & 0.016778 & 0.118899 & 0.221330 & 0.422590 \\
\hline $\operatorname{GDP}(-1)$ & 0.156867 & 0.204382 & 0.168855 & 0.481024 \\
\hline $\operatorname{GDP}(-2)$ & 0.107754 & 0.112107 & -0.131570 & 0.417146 \\
\hline GMS(-1) & 0.235863 & 0.061007 & 0.055558 & 0.353952 \\
\hline GMS(-2) & 0.061834 & -0.085298 & -0.065941 & -0.335882 \\
\hline c & -1.239079 & 0.010711 & $7.104329 * *$ & $7.512367^{* \star}$ \\
\hline R-squared & 0.765182 & 0.513664 & 0.617156 & 0.613236 \\
\hline Adj. R-squared & 0.675728 & 0.328393 & 0.471310 & 0.465897 \\
\hline
\end{tabular}

** denotes significant at 5 per cent.

Budget deficit seems to have a positive effect on inflation in South Africa at lag two, although the coefficient is not statistically significant. Economic growth and money supply also show some impact on the inflationary process. The passed values of the all the variables have the mixed signs, for example, the coefficient at lag one for inflation turns out to positive and highly significant. Inflation lagged twice bears a negative sign implying that current inflation is affected negatively by past two years figure.

2 See Granger (1969). 


\subsection{Impulse response functions}

Appendix A shows the impulse response functions of the variables included in the VAR to both a monetary and fiscal policy shocks. The dashed lines in each graph show the 95\% confidence bands. The impulse response functions are plotted over a 10 - year horizon. It is expected that during a monetary shock, GDP, budget deficits and inflation will fall. Inflation reacts negatively to a shock in monetary policy. This is shown by solid line falling in period one up to period ten. The graph that shows response of CPI to GMS suggests that the unexpected increase in money supply tends to provide a positive jolt to inflation about three years later. Inflation will then subside from end of year three up until year six, after which it will be stable.

Inflations reacts positively to a shock in budget deficit, meaning when budget deficit increases unexpectedly, there will be slide rise in inflation from year two till year five. After period five, it then becomes stable throughout. The response of money supply to other variables, including inflations shows both negative and positive at different time periods. When inflation falls unexpectedly in period one, money supply fall and then increase from year two up until period five. In period one, a negative response is experienced, though this happens only for a short period of time. A positive shock happens for at least four years and then stability is observed.

In the deficit - inflation relationship, we observe that a price shock brings a negative response to budget deficit in year two and positive in year three. The average response of budget deficit to inflation is fairly negative for at least ten years. On the other hand, budget deficit responds negatively to growth of money supply up to year four. At this period, the impulse attains a maximum of -0.094 . Budget deficit is found to be responding positively to shocks in DGP from year one to year eight.

\subsection{Cointegration}

The test procedure is to move through from the most restrictive model at each stage to compare the trace or maximal eigen value statistic to its critical value and only stop the first time the null hypothesis is not rejected. The trace (table $3(a))$ shows that there are two cointegrating vectors while the Max-eigenvalue (table $3(b)$ ) suggests only one cointegration vector.

Table 3 (a) : Trace test results

\begin{tabular}{lllll}
\hline No. of CE(s) & Eigenvalue & Trace Stat & $95 \%$ interval & Prob.** $^{*}$ \\
\hline None * & 0.649875 & 61.47835 & 47.85613 & 0.0016 \\
At most 1 * & 0.502992 & 31.04384 & 29.79707 & 0.0358 \\
At most 2 & 0.290625 & 10.76852 & 15.49471 & 0.2261 \\
At most 3 & 0.027570 & 0.810760 & 3.841466 & 0.3679 \\
\hline
\end{tabular}

Table 3 (b): Max- Eigenvalue test results

\begin{tabular}{|c|c|c|c|c|}
\hline No. of $\mathrm{CE}(\mathrm{s})$ & Eigenvalue & Max-E. Stat & $95 \%$ interval & Prob.** \\
\hline None * & 0.649875 & 30.43451 & 27.58434 & 0.0209 \\
\hline At most 1 & 0.502992 & 20.27532 & 21.13162 & 0.0655 \\
\hline At most 2 & 0.290625 & 9.957755 & 14.26460 & 0.2147 \\
\hline At most 3 & 0.027570 & 0.810760 & 3.841466 & 0.3679 \\
\hline
\end{tabular}

* denotes rejection of the hypothesis at the 0.05 level

**MacKinnon-Haug-Michelis (1999) p-values 
A typical cointegrating relationship for inflation, budget defict and money growth gives a normalized equation $C P I=-1.7484 B D+5.1106 G D P+1.1987 M S$. We therefore carried out the long-run regression analysis based on those two cointegrating vectors. We first normalize inflation and run a regression. This implies that budget deficit and money exert negatively towards inflation while budget deficit affect it positively.

\section{Conclusion}

The policy implication of this study is that inflation in South Africa is mainly due to increases in budget deficit and the growth of money supply. The study has shown that inflation in South Africa is largely structural in nature and that the monetary authorities have limited control over the main determinants thereof as the fiscal side of the economy contributes towards inflation process. This suggests that it would be difficult to achieve the objective of price stability to the levels prevailing in the main trading partners ${ }^{3}$. The study shows that fiscal budget deficit and growth of money supply have equally contributory impact on South Africa's inflationary process. Therefore, in order for South Africa to control its inflation rates, it needs to cut the size of government deficit perhaps by cutting the size of its bureaucracy drastically. The policy of cutting government expenditures to control domestic inflation was also advocated by Corsepius (1989) when addressing the Peruvian experience. The government each year increases the amount of social grants and these have to be held constant for sometime. This will help in the reduction of government expenditure. Perhaps equally important, this direct and potent impact of budget deficit on inflation is not contingent upon debt monetization since the monetary authorities are trying to maintain the significant impact of money growth on inflation. It should be noted that, compared to other determinants of inflation, budget deficit and money growth seem to have a quicker and stronger effect on inflation. It seems useful to note that our study's evidence for the significance impact of budget deficit on inflation is inconsistent with the Ricardian Equivalence hypothesis (Barro, 1974). Both the fiscal and monetary authorities must act such that budget deficit is reduced and that money supply is not excessive, as that leads to inflation. Like we pointed out that high budget deficits are not desirable at all, they lead to inflation if monetized, reduce national savings and thus crowd out private investment. Since economic theory suggests that there is a positive relationship between investment and economic growth, crowding out private investment leads to a decline in economic growth. The control of inflation requires deliberate action by the budgetary authorities if the monetary is not to be excessive.

\section{References}

Akcay, O.C, Ozmucur, S. and Alper, C.E. (1996). Budget Deficits, Money supply and Inflation: Evidence from low and High frequency Data for Turkey. Research Paper. Department of Economics, Bogazici University.

Barro, R. (1974) Are government bonds net wealth? Journal of political economy. 82:1095 -1117

Branson, W.H. (1989). Macroeconomic theory and Policy (3rd ed.). Harper and Row Publishers, New York.

Cagan, P. (1956). The monetary dynamics of hyperinflation. In studies in the quantity Theory of money,ed Milton Friedman. University of Chicago Press. Chicago.

Corsepius, U. (1989). Peru at the brink of economic collapse: Current problems and Policy options. Keil Discussion Papers, Keil Institute of World Economics, West Germany. Web site https://www.econstor.eu/dspace/bitstream /10419/48052/1/255995180.pdf.

Darrat, A.F. (1985). Inflation and federal budget deficits: some empirical results, Public Finance Annual. 13:206-215. (2000). Are budget deficits inflationary? A reconsideration of evidence. Applied

Dornbusch, R. and Fischer, S. (1993). Moderate inflation. World Bank Economic Review, 7(1): 1-44.

Dweyer, G.P. (1982). Inflation and Government deficits. Economic Inquiry. 20:315-329.

Frenkel, J.A. (1977). The forward exchange rate, expectations and the demand for money: The German hyperinflation. American Economic Review, 67(4):653-670.

Granger, C.W.J. (1969). Investigating Causal Relations by Econometric Models and Cross-Spectral Methods. Econometrica, 37(3): 424438.

Hondroyiannis, G. and Papapetrou, E. (1992). Are budget deficits inflationary? A Cointegration approach. Applied Economics Letters, 4:493-496.

Jacobs, R.L. (1977). Hyperinflation and the supply of money. Journal of Money, Credit and Banking, 9(2):287-303.

Johansen, S. (1988). Statistical analysis of Cointegration vector. Journal of Economic Dynamics and control, 12:231-254.

Juselius, K. ( 1990). Maximum likelihood estimation and inference on Cointegration with application to the demand for money. Oxford Bulletin of Economics and statistics, 52(2):169-210.

${ }^{3}$ Including countries in the BRICS blog 
Keynes, J.M. (1971). A track on monetary reform, in The collected writings of John Maynard Keynes,. Vol 4.

Mishkin, F.S. ( 1997). The economics of Money, Banking and Financial markets (5th.$e d)$, Addison Wesley, Marbo, England.

Neyapti, B. (2012). Budget deficits and inflation: The role of central bank independence and financial market development. Contemporary Economic policy, 21(4): 458-475.

Sargent, T.J. and Wallace, N. (1973). Rational expectations and the dynamics of hyperinflation. International Economic Review, Vol 14 (2):328-350.

(1981). Some unpleasant monetarist arithmetic. Federal Reserve Bank of Minneapolis Annual Review. 5: 1-17.

South African Reserve Bank. (1996). Annual Economic Report 1995. Pretoria.

Tekin-Koru, A. and Ozmen, E. (2003). Budget deficits, Money growth and Inflation: The Turkish evidence. Applied Economics,35:591596.

\section{Appendix A: Impulse response functions}

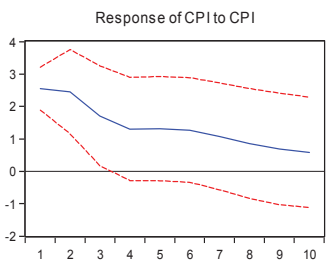

Response of GMS to CPI

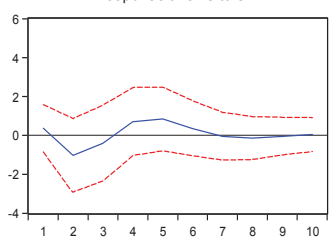

Response of GDP to CPI

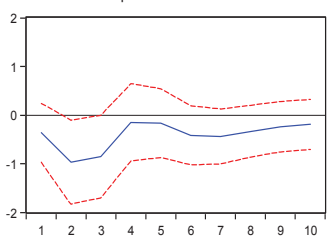

Response of BD to CP

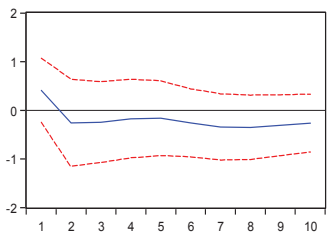

Response to Cholesky One S.D. Innov ations \pm 2 S.E.

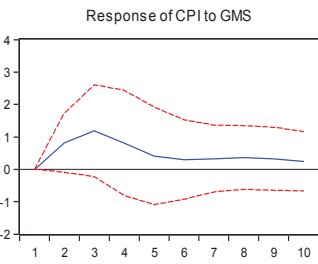

Response of GMS to GMS
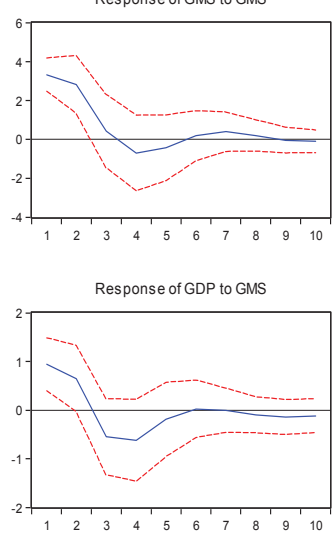

Response of BD to GMS

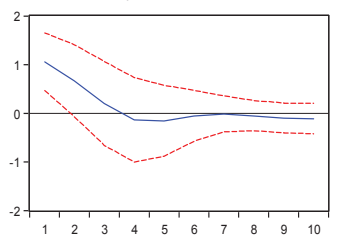

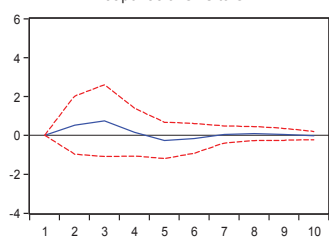

Response of GDP to GDP

Response of CPI to GDP
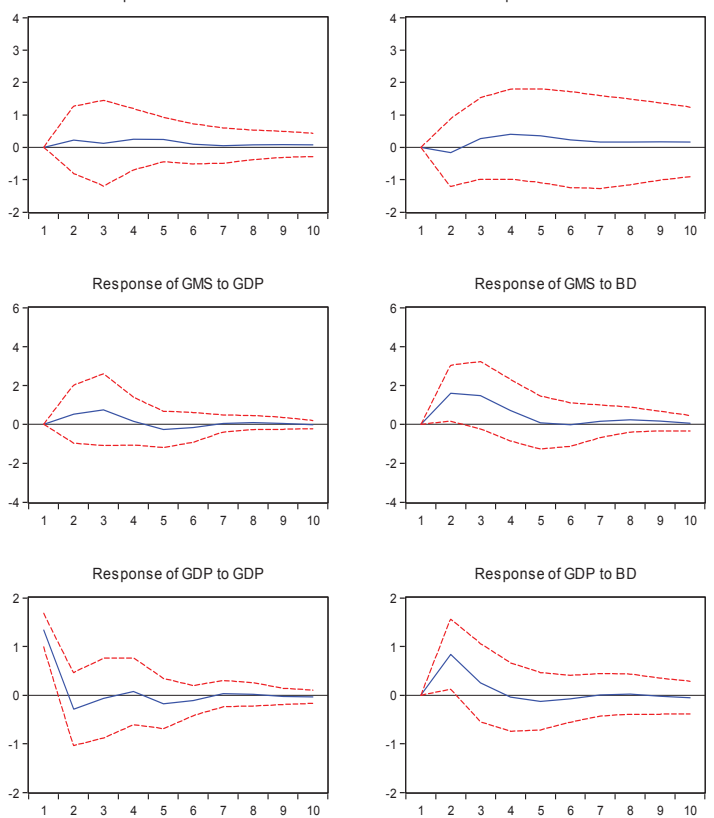

Response of $\mathrm{BD}$ to $\mathrm{BD}$

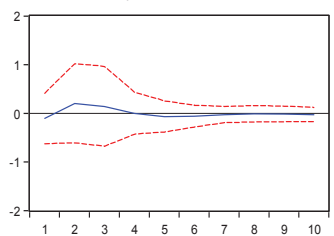

Response of $\mathrm{CPI}$ to $\mathrm{BD}$
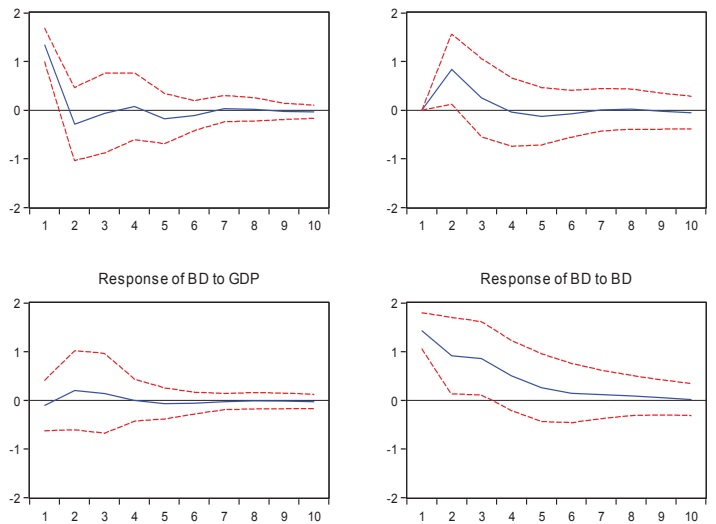